\title{
COL4A3 Gene
}

National Cancer Institute

\section{Source}

National Cancer Institute. COL4A3 Gene. NCI Thesaurus. Code C24306.

This gene plays a role in the compositional and structural regulation of basement membranes. 